\title{
ASSESSMENT OF BIOMASS RESOURCES FROM THE CARE OF PINE STAND
}

\author{
Alina Kowalczyk-Juśko', Roman Rybicki', Radomir Obroślak', Andrzej Mazur \\ 1 Department of Environmental Engineering and Geodesy, University of Life Sciences in Lublin, Leszczyńskiego \\ Str. 7, 20-069 Lublin, Poland, e-mail: alina.jusko@up.lublin.pl, roman.rybicki@up.lublin.pl, radomir.obroslak@ \\ up.lublin.pl, amazur70@op.pl
}

Received: 2016.08.01

Accepted: 2016.09 .26

Published: 2016.11.01

\begin{abstract}
The paper presents the results of the research of the potential of woody biomass derived from the afforestation tending. Evaluation of the quantity and energy characteristics of biomass acquired from care of 20 year old pine stand (late cutting). Moreover, based on the CSO data about the size of afforestation in subsequent years, the amount of waste from plantings care obtainable in the country was determined. It was found that the surfaces for afforestation already in the phase of greenwood can be useful source of energy. Biomass sourced from the care of plantings can be valuable raw material, especially at the local level.
\end{abstract}

Keywords: pine afforestation, care of tree stand, wastes

\section{INTRODUCTION}

The provisions of the Directive [2009/28/EC] of the European Parliament and of the Council on the promotion of the use of energy from renewable sources impose Member States the obligation to obtain levels of energy production from renewable sources not less than $20 \%$ of gross final energy consumption in 2020. This level is different for different countries and for Poland amounts $15 \%$. Different are also renewable energy sources (RES) used by individual countries. In many Member States, the dominant of renewable energy sources are solid biofuels, that accounted in 2013 for about $45.9 \%$ of energy from renewable sources. The importance of solid biomass as an energy source is much larger in Poland: its share of obtaining energy in 2013 amounted $80.3 \%$, whereas in $2014-76.6 \%$ [CSO 2015a]. This results from the slow pace of development of distributed electricity sources in Poland. In the heat and power plants, energy production is based mainly on coal. They do not install a biomassfired boilers but only co-combustion technology of solid biomass are used.

Analyzing the structure of production of energy from renewable sources, you can get the im- pression that this is a favorable situation for rural areas that can become the areas of aquisition of biomass. Unfortunately, the data of the sources of biomass used in Polish power sector shows that the import of solid biomass has increased almost eight times in the years 2008-2014 (from 423 thousand $\mathrm{Mg}$ to 3591 thousand $\mathrm{Mg}$ ) [Gradziuk and Gradziuk 2015]. For energy purposes are mainly used waste from forestry and wood industry, straw (processed into pellet form), but also (originating in Ukraine, Indonesia, Russia and Malaysia) sunflower husks, nut shells and palm oil cakes. At the same time lack of rational use of biomass from dispersed sources is often observed.

Dispersed, untapped sources of biomass in Poland are afforestation implemented according to the National Program of Forested Areas Increase [KPZL 2003]. Trees planting on agricultural land allow develop unsuitable for agriculture marginal land, thereby avoiding the uncontrolled succession and degradation of this land.As a result of National Program of Forest Areas Increase, in the years 1995 - 2014 was afforested 274.4 thousand hectares of land $(58.5 \%$ of this are pine plantings). In this 131.3 thousand hectares (48\%) is the land of the State Treasury, while 142.9 thousand hectares (52\%) - non-state land [CSO 2015b]. 
As an integral part of the landscape, forest performs different functions (production, ecological and social). In order to improve its resilience and value in use, human (a forester) activity is also necessary. By using a knowledge of nature foresters manage forests and tending them. Under the concept of tending of forest, you must understand all the treatments (mainly various types of cutting and thinning) performed since inception growing up to maturity [Szymański 2000, Murat 2002].

Production of waste classified as waste from forestry with the code 020107 [Dz. U. poz 1923] is inextricably linked with the tending of forest stand. Sometimes, especially in the first two phases of development (growing and greenwood) these are wastes of very low suitability as wood raw material [Gorzelak et all. 2001] but these may be a valuable energy resource.

The aim of the study is to evaluate the merits of acquiring waste from tending pine stand being in the phase of greenwood (late cutting and brushing) and use them as an energy source. The amount of waste obtained from unit area, their energy value and the amount of waste possible to obtain in the country (based on CSO data about the size of afforestation on each year) were analyzed.

\section{MATERIAL AND METHODS}

The research material was the waste from tending of pine forest stand planted in 1992. It is a private forest. Land plot (plot number
335 - Fig. 1) is located in the village of Brzeziny (Stężyca commune, Ryki district, Lublin Voivodeship). The ground on which planting were made is soil Class VI with the granulometric composition of fine loose sand $(91 \%$ sand, $8 \%$ dust and $1 \%$ clay), with very acidic $\mathrm{pH}$ value $(\mathrm{pH}=3.73 \mathrm{KCl})$, low phosphorus and potassium content $\left(\mathrm{P}_{2} \mathrm{O}_{5}-9.5 \mathrm{mg} / 100 \mathrm{~g}, \mathrm{~K}_{2} \mathrm{O}-6.7\right.$ $\mathrm{mg} / 100 \mathrm{~g}$ ) and very low content of magnesium $(\mathrm{Mg}-1.7 \mathrm{mg} / 100 \mathrm{~g})$. Forest currently is in the phase of greenwood (phase of growing was completed). Improvement cutting and brashing were carried out by the forest owner at the end of March 2013. According to the phase of forest stand development (Fig. 2a) such operations are called late cutting.

Test specimens (wastes not developed by the farmer - Fig. 2b) was collected from three surfaces with dimensions $10 \times 10$ meters. Obtained results were expressed per 1 hectare. After collecting, the material has been shredded (Fig. 2c) on a wood splitter (constructed by the farmer - no symbol of the machine) and weighed (with the accuracy of $0.01 \mathrm{~kg}$ ) on the hanging scales AXIS B 30. Subsequently, samples were taken for laboratory analysis - measurement of humidity, gross calorific value (GCV) and ash content. The humidity test of waste was carried out by using the weight method based on PN-93/Z-15008/02. Measuring the GCV, and calculating the net calorific value $(\mathrm{NCV})$ of the waste were based on the PN-EN 14918: 2010. The process involves complete combustion of the sample of waste in pure

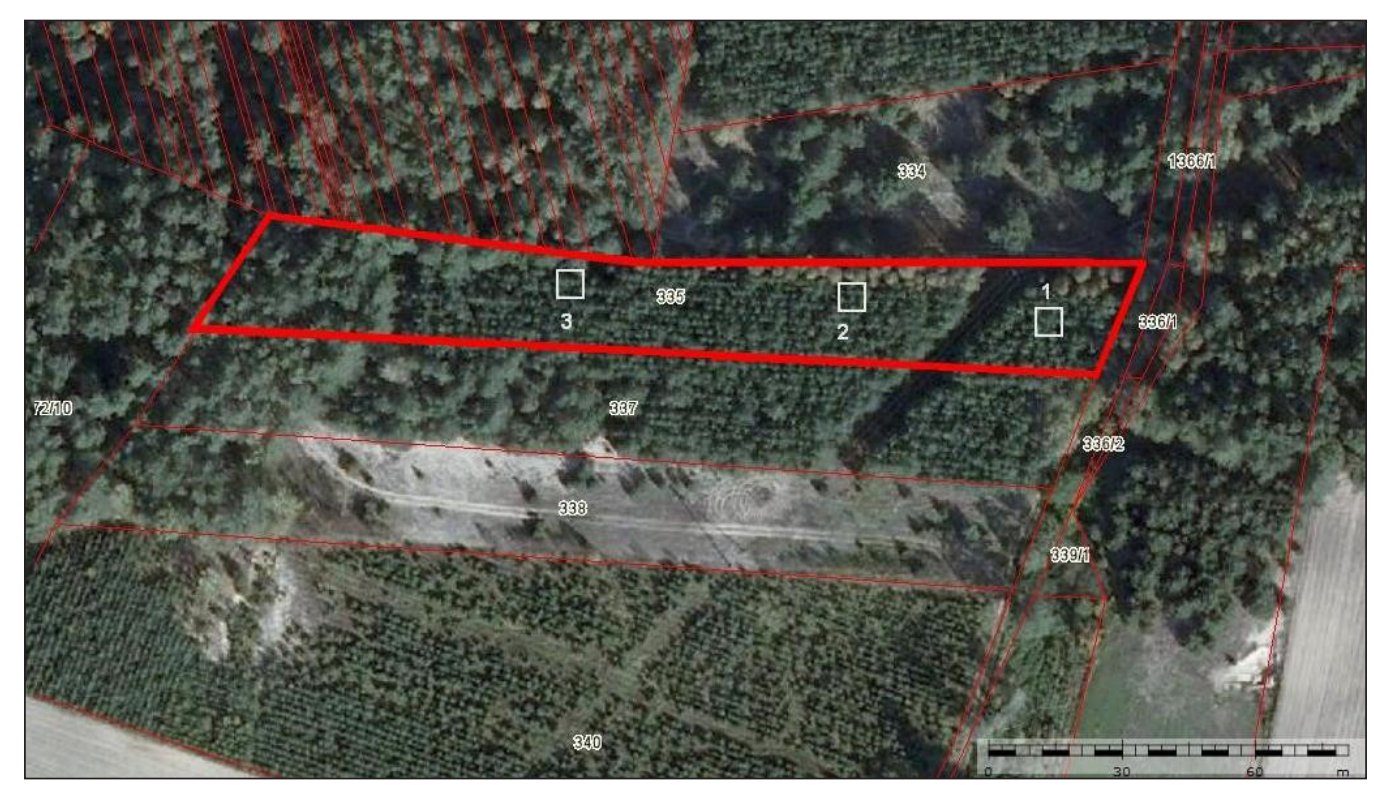

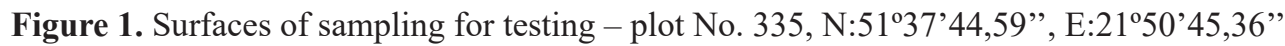
(based on geoportal.gov.pl) 

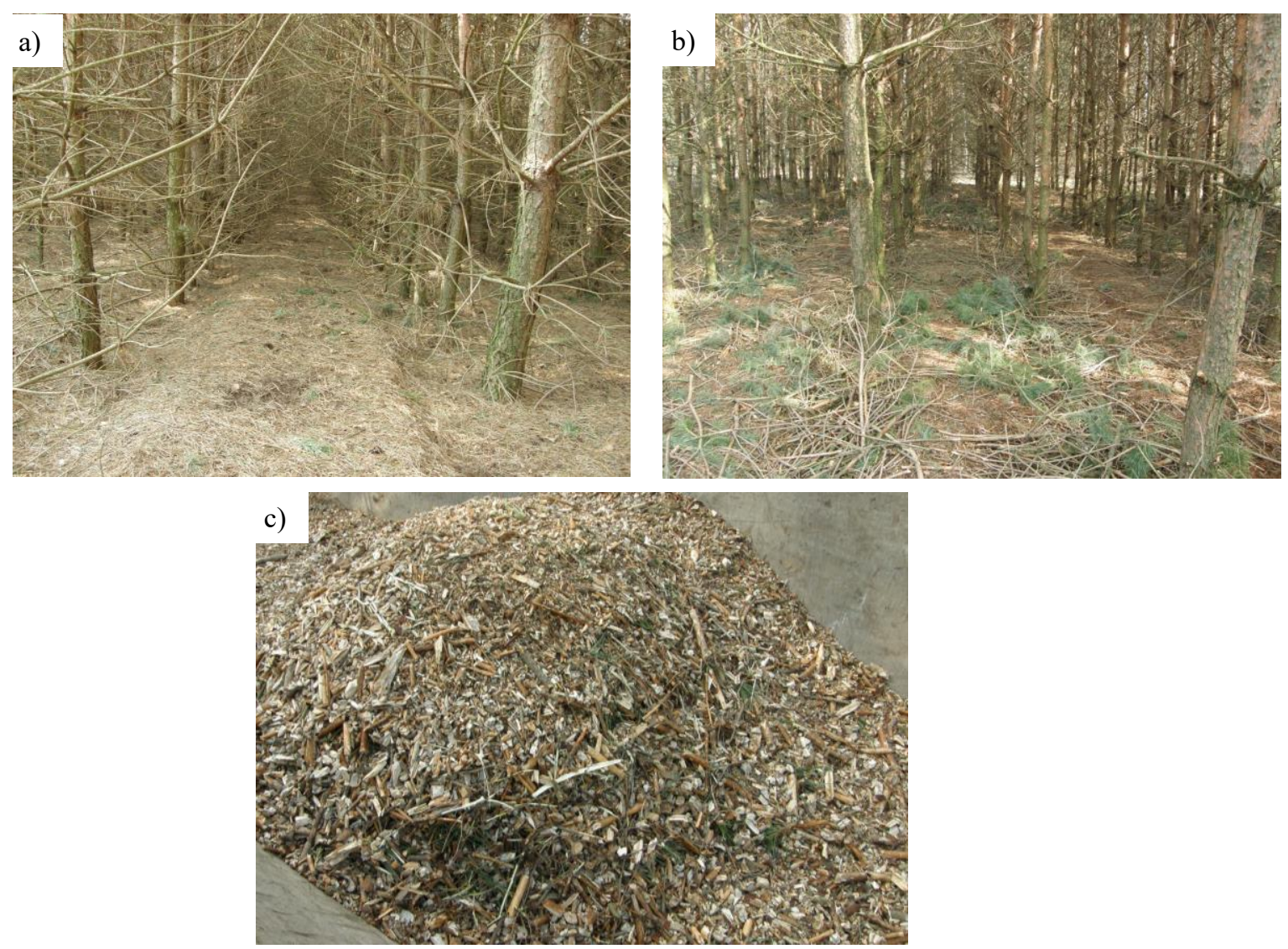

Figure 2. a) Tree stand before tending; b) Tree stand after tending; c) Wastes after shredding.

oxygen in a calorimeter KL-12Mn. Net calorific value of samples was calculated by diminishing the obtained value of GCV by vaporization of water vapor present in the exhaust (arising from the combustion of hydrogen contained in the fuel). For this purpose, averaged results of content of hydrogen in the dry matter of pinewood taken from the Kokociński [2005] publication were used. Ash content were based on the PN-EN 14775 2010U, whilst bulk density was based on the PN-EN 151032010.

\section{RESULTS AND DISCUSSION}

One of the basic parameters determining the suitability of biomass as a fuel for technical purposes is humidity content. Besides the elementary composition, just the humidity is highly dependent on the calorific value of all types of biomass [Niedziółka and Zuchniarz 2008] wherein an increase in humidity leads to decrease in the calorific value of the biomass. Equally important is the ash content of the biomass. In addition, moisture plays a significant role in the combustion process, it is also important in the assessment of stor- age capacities and affects the weight of biomass [Wandrasz and Wandrasz 2006].

Humidity of the tested waste (at the operational state) were ranged from $34.61 \%$ (area 2) to $37.10 \%$ on area 1 (average $35.46 \%$ ) - Table 1 . Differences at the humidity results mainly from the organization of work of collection of waste generated during the care of trees. Harvesting and shredding of branches (waste) from the surface 2 and 3 (Fig. 1) was carried out immediately after thinning. However in the case of the surface 1 cutting were made in the morning while waste collection in the afternoon. Branches were damp because they were lying couple of hours on the ground. This resulted in increasing of moisture content about $2.5 \%$ relative to the branches collected directly from trees. The ash content of the test samples was $0.6 \%$ and this value does not deviate from the literature [Komorowicz et al. 2009].

The main parameter that must be taken into account in assessing the merits of acquiring waste of tree care and use them as an energy source is their energy value. For individual surfaces three tests of GCV of samples dried in a laboratory drier (dry mass) were performed. Average values, standard deviation and coefficient of varia- 
Table 1. Physical characteristics of wastes (wood chips)

\begin{tabular}{|c|c|c|c|c|c|c|c|c|c|c|}
\hline \multirow[b]{3}{*}{ Specification } & \multirow{2}{*}{\multicolumn{3}{|c|}{$\begin{array}{c}\text { Mass } \\
{\left[\mathrm{kg} \cdot \mathrm{ha}^{-1}\right]}\end{array}$}} & \multicolumn{6}{|c|}{ Bulk density $\left[\mathrm{kg} \cdot \mathrm{m}^{-3}\right]$} & \multirow[b]{3}{*}{$\begin{array}{c}\text { Humidity } \\
\text { (operational } \\
\text { state) } \\
{[\%]}\end{array}$} \\
\hline & & & & \multicolumn{3}{|c|}{ not compacted } & \multicolumn{3}{|c|}{ compacted } & \\
\hline & 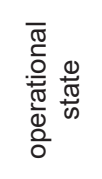 & 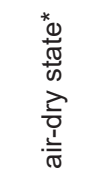 & 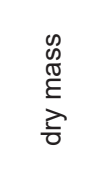 & 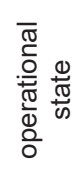 & 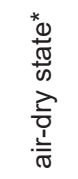 & 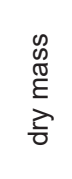 & 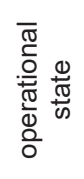 & 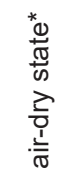 & 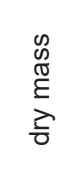 & \\
\hline Area 1 & 18693 & 13833 & 11758 & 259 & 193 & 163 & 323 & 238 & 203 & 37.10 \\
\hline Area 2 & 16590 & 12762 & 10848 & 245 & 188 & 160 & 306 & 236 & 201 & 34.61 \\
\hline Area 3 & 17360 & 13345 & 11343 & 246 & 189 & 161 & 309 & 237 & 202 & 34.66 \\
\hline Average & 17546 & 13322 & 11324 & 249 & 190 & 161 & 313 & 237 & 202 & 35.46 \\
\hline
\end{tabular}

* air-dry state - humidity $15 \%$.

tion were calculated. The average GCV of dry mass of wastes was $21.09 \mathrm{MJ} \cdot \mathrm{kg}^{-1}$ (Table 2). Net calorific value of dry mass was calculated taking as the Kokociński [2005] the average hydrogen content of pinewood of $6.1 \%$. Average of this value was $19.42 \mathrm{MJ} \cdot \mathrm{kg}^{-1}$ (standard deviation 0.24 $\mathrm{MJ} \cdot \mathrm{kg}^{-1}$, coefficient of variation $1,26 \%$ ). While the ash content at the test samples equal $0.6 \%$, the NCV of dry ash-free mass was $19.53 \mathrm{MJ} \cdot \mathrm{kg}^{-1}$. For air-dry (average humidity 15\%) the average $\mathrm{NCV}$ of the tested wood chips was $16.13 \mathrm{MJ} \cdot \mathrm{kg}^{-1}$. The NCV of operational state of wood chips (average humidity $35.5 \%$ - Table 1) was about $11,64 \mathrm{MJ} \cdot \mathrm{kg}^{-1}$. These values do not deviate from the values given by other authors (Gradziuk et al. 2003, Kokociński 2005, Komorowicz et al. 2009, Niedziółka and Zuchniarz 2006].
Another parameter that must be taken into account whilst assessing the merits of acquiring waste of tree care and use them as an energy source next to the calorific value is the amount of wastes possible to obtain per unit area. In case of the analyzed afforestation the mass (in the operational state) of generated wastes - branches from tree brashing expressed per 1 hectare ranged from 16.59 $\mathrm{Mg}$ (surface 2) to $18.69 \mathrm{Mg}$ (surface 1) - Table 1. After drying to the air-dry state, these values are reduced appropriately to 12.76 $\mathrm{Mg}$ and $13.83 \mathrm{Mg}$ (average13.32 Mg). Useful parameter especially when transport organization is also the bulk density. Moisture content in the case of this parameter is also important. The bulk density of not compacted shredded wastes averaged $249 \mathrm{~kg} \cdot \mathrm{m}^{-3}$ for operational state and

Table 2. Fuel properties of wastes (wood chips)

\begin{tabular}{|c|c|c|c|c|c|}
\hline Specification & 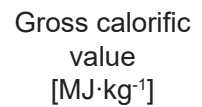 & 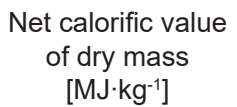 & 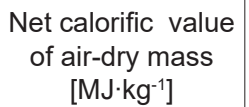 & 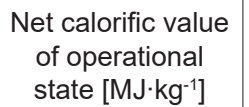 & $\begin{array}{c}\text { Ash } \\
\%\end{array}$ \\
\hline \multicolumn{6}{|l|}{ Area 1} \\
\hline sample 1 & 21.29 & 19.79 & 16.45 & 11.52 & 0.6 \\
\hline sample 2 & 21.14 & 19.52 & 16.21 & 11.35 & 0.6 \\
\hline sample 3 & 20.94 & 19.22 & 15.96 & 11.16 & 0.6 \\
\hline Average & 21.13 & 19.51 & 16.21 & 11.34 & 0.6 \\
\hline \multicolumn{6}{|l|}{ Area 2} \\
\hline sample 1 & 20.97 & 19.33 & 16.05 & 11.77 & 0.6 \\
\hline sample 2 & 21.32 & 19.63 & 16.31 & 11.97 & 0.6 \\
\hline sample 3 & 20.80 & 18.96 & 15.74 & 11.54 & 0.6 \\
\hline Average & 21.03 & 19.31 & 16.04 & 11.76 & 0.6 \\
\hline \multicolumn{6}{|l|}{ Area 3} \\
\hline sample 1 & 21.08 & 19.31 & 16.04 & 11.75 & 0.6 \\
\hline sample 2 & 21.12 & 19.52 & 16.21 & 11.88 & 0.6 \\
\hline sample 3 & 21.15 & 19.50 & 16.22 & 11.89 & 0.6 \\
\hline Average & 21.12 & 19.51 & 16.23 & 11.90 & 0.6 \\
\hline Total average & 21.09 & 19.42 & 16.13 & 11.64 & 0.6 \\
\hline Standard deviation & 0.16 & 0.24 & 0.21 & 0.27 & \\
\hline Coefficient of variation [\%] & 0.79 & 1.26 & 1.29 & 2.34 & \\
\hline
\end{tabular}


$190 \mathrm{~kg} \cdot \mathrm{m}^{-3}$ for air-dry state. For compacted state, the mass of 1 cubic meter of shredded wastes averaged $313 \mathrm{~kg}$ for operational state, and 237 $\mathrm{kg}$ for air-dry state. These values are within the range shown by the literature [Gradziuk et al. 2003], however, these are the values of the lower range. Therefore, a bulk density of investigated wood chips should be assessed as low. The cause of this is large heterogeneity (hindering of compaction) of the particles after shredding (Figure 2c) where a large volume is occupied by free spaces. This is due to the type of shredded material (branches with diameter not more than 30 $\mathrm{mm}$ ) and imperfections of shredding machine (self-built of farmer).

The Central Statistical Office data [CSO 2015b] shows that as a result of implementation of the National Program of Forested Areas Increase, on average in the period 1995-2014, per year on private land were afforested 7.1 thousand hectares of land. From this, $58.5 \%$ are pine forests.

Therefore it must be assumed that the annual need for late cutting and tree brashing (such as planting analyzed on this study - age $20-25$ years), in the case of pine stands will occur about 4.1 thousand hectares of land. From such surface area it will be able to obtain wastes (mainly branches from brashing) such as examined in this study.

Assuming that 1 ha can be obtained average 13.32 Mg air-dry wastes (wood chips) such as shown in the work, only tending of non-state afforestation can get about 54.6 thousand $\mathrm{Mg}$ of wastes per year (almost the same amount of state land additionally). Taking the average airdry net calorific value of investigated wastes about $16.13 \mathrm{MJ} \cdot \mathrm{kg}^{-1}$, the theoretical amount of possible to get energy could reach 880.7 TJ. Therefore, the obtainable biomass could replace 41.8 thousand $\mathrm{Mg}$ of hard coal, 24.9 thousand $\mathrm{m}^{3}$ of fuel oil, 33.8 million $\mathrm{m}^{3}$ of natural gas or 68.8 thousand $\mathrm{Mg}$ of straw.

\section{CONCLUSIONS}

On the basis of the conducted research, the merits of acquiring waste from care of pine stand in the phase of greenwood (late cutting and brashing) and use them as an energy source, following conclusions can be formulated.
1. Late cutting of pine stands can contribute to the formation of relatively large amount of wastes (mainly branches) - in the case of an investigational forest one hectare can provide about 17.5 $\mathrm{Mg}$ of humid wood chips.

2. After drying to air-dry state (humidity $15 \%$ ) obtainable mass of wastes from 1 hectare may total about $13.3 \mathrm{Mg}$.

3. The net calorific value of humid wood chips (average humidity of $35.5 \%$ ) was about 11.64 $\mathrm{MJ} \cdot \mathrm{kg}^{-1}$, dried on the open air - $16,13 \mathrm{MJ} \cdot \mathrm{kg}^{-1}$, completely dry $-19.42 \mathrm{MJ} \cdot \mathrm{kg}^{-1}$.

4. Examined wood chips (on the air-dry state) related to 1 hectare could theoretically provide the equivalent of $10.2 \mathrm{Mg}$ of hard coal, $6.1 \mathrm{~m}^{3}$ of fuel oil, 8.2 thousand $\mathrm{m}^{3}$ of natural gas or $16.8 \mathrm{Mg}$ of straw.

5. Most of the work of harvesting of wastes from forest stand tending, such as shown in work, must be done by hand, and organization of harvesting of branches has an influence on humidity of obtained biomass.

6 . The results show that the areas designed for afforestation, already in the phase of greenwood can be a useful area of energy, and sourced biomass from tending of plantings can be a valuable resource, especially at the local.

7. Tending of plantings, such as the plantings analyzed at this work, will require about 4,1 thousand hectares of plantings on private land annually. This way you can get about 54.6 thousand $\mathrm{Mg}$ of biomass per year.

\section{REFERENCES}

1. CSO 2015a. Energy from renewable sources in 2014. Central Satistical Office. Statistical Information and Elaboration. Warsaw (In Polish).

2. CSO 2015b. Forestry. Central Satistical Office. Statistical Information and Elaboration. Warsaw (In Polish).

3. Directive 2009/28/EC of the European Parliament and of the Council of 23 April 2009 on the promotion of the use of energy from renewable sources.

4. Dz. U. 2014 poz. 1923. Regulation of the Minister of Environment of 9 December 2014 regarding waste catalog (In Polish).

5. Gorzelak A., Gil W., Głaz J., Kolk A., Suwała M., Zachara T., Zając S. 2001. Small holding forests management. Ed. IBL. Warsaw (In Polish). 
6. Gradziuk P., Grzybek A., Kowalczyk K., Kościk B. 2003. Biofuels. Ed. Wieś Jutra. Warsaw (In Polish).

7. Gradziuk B., Gradziuk P. 2015. Foreign trade of biomass for energy purposes in Poland in the years 2008-2014. Barometr Regionalny. T. 13, nr 3, 151-159.

8. Kokociński W. 2005. Anatomy of the wood. Ed. Prodruk. Poznań (In Polish).

9. Komorowicz M., Wróblewska H., Pawłowski J. 2009. Chemical composition and energetic properties of biomass from selected renewable resources. Ochr. Środ. i Zas. Naturalnych, nr 40, 402-210 (In Polish).

10. KPZL 2003. National Program of Forested Ar- eas Increase. Ministry of Environment. Warsaw (In Polish).

11. Murat E. 2002. Detailed silviculture. Ed. Publishing Editorial „Wydawnictwo Świat”. Warsaw (In Polish).

12. Niedziółka I., Zuchniarz A. 2006. An energetic analysis of selected plant biomass samples. Motrol, 8A, 232-237 (In Polish).

13. Szymański S. 2000. Ecological basis of silviculture. PWRiL. Warsaw (In Polish).

14. Wandrasz J.W., Wandrasz A.J. 2006. Formed fuels. Biofuels and waste fuels in thermal processes. Ed. Seidel-Przywecki Sp. z o.o., Warsaw (In Polish).

Pracę dofinansowano ze środków Wojewódzkiego Funduszu Ochrony Środowiska i Gospodarki Wodnej w Lublinie. 